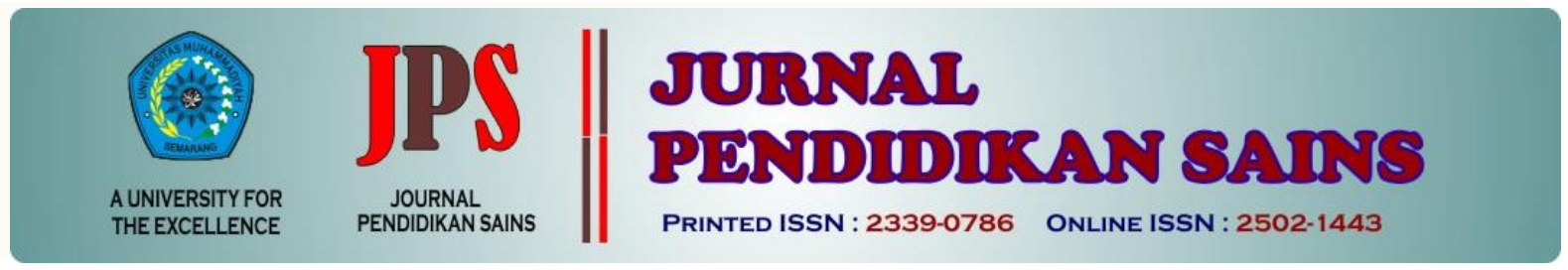

http://jurnal.unimus.ac.id/index.php/JPKIMIA

\title{
EFEKTIVITAS MODEL PROBLEM BASED INSTRUCTION BERPENDEKATAN ETNOSAINS UNTUK MENINGKATKAN KETERAMPILAN GENERIK SAINS
}

\author{
Oleh: \\ Tin Rosidah ${ }^{1)}$, Fitria Fatichatul Hidayah ${ }^{2)}$, Andari Puji Astuti ${ }^{3)}$ \\ ${ }^{1,2,3}$ S1 Pendidikan Kimia, Fakultas Matematika dan Ilmu Pengetahuan Alam, Universitas \\ Muhammadiyah Semarang
}

\begin{tabular}{|c|c|}
\hline Article history & Abstract \\
\hline 2018-10-04 & \multirow{5}{*}{$\begin{array}{l}\text { This study is a quasi-experimental method with a time series design } \\
\text { that aims to determine the effect of problem-based learning models } \\
\text { with an ethnoscience science approach to students' generic science } \\
\text { skills. The research subjects used were 10th grade students of } \\
\text { Muhammadiyah Grobogan High School. The results of this study } \\
\text { obtained N-Gain values for each different aspect. Conceptual aspects } \\
\text { of N-Gain are } 0.776 \text {, mathematical modeling aspects are } 0.625 \text {, } \\
\text { symbolic language assumptions are } 0.607 \text {, direct observation aspects } \\
\text { are } 0.725 \text {, and indirect observation aspects are } 0.604 \text {. Based on the t- } \\
\text { test that has been done, it is obtained that the data of sig } 2 \text { tailed values } \\
\text { is } 0.00 \text { where } 0.00<0.05 \text {, meaning that there is a significant influence } \\
\text { on the use of problem-based learning learning models with an ethno- } \\
\text { scientific approach to students' generic science skills. This model is } \\
\text { also effective in improving students' genetic skills in stoichiometry } \\
\text { material seen from the many effects sizes. }\end{array}$} \\
\hline $2018-10-29$ & \\
\hline $2019-02-14$ & \\
\hline Keyword: & \\
\hline $\begin{array}{l}\text { Kata kunci: Problem Based } \\
\text { Instruction, ethnoscience, } \\
\text { generic science skills, } \\
\text { stoichiometry }\end{array}$ & \\
\hline
\end{tabular}

\section{Pendahuluan}

Pendidikan memiliki peran penting dalam perkembangan hidup manusia sebagai usaha yang terencana untuk mewujudkan proses pembelajaran yang aktif sehingga siswa dapat mengembangkan potensi yang ada pada dirinya. Potensi tersebut antara lain spiritual keagamaan, pengendalian diri, kepribadian, kecerdasan, akhlak mulia, serta keterampilan yang diperlukan dirinya, masyarakat, bangsa, dan negara (Priyatno, 2009). Bila potensipotensi tersebut dapat berkembang dengan baik dalam diri siswa, maka siswa akan memiliki prestasi belajar yang baik dalam segala bidang.
Nilai KKM yang baik tidak dapat dijadikan acuan dalam menentukan kemampuan setiap siswa. Karakter siswa yang mudah lupa terhadap materi pelajaran yang bersifat hafalan dapat mempengaruhi prestasi belajar yang dimiliki oleh siswa. Siswa sulit memahami simbol dan lambang kimia karena siswa lebih suka materi pelajaran yang bersifat hitungan daripada hafalan (Rosidah, Andari, dan VDR Andri 2017). Hal ini dapat menghambat perkembangan keterampilan generik sains yang dimiliki siswa. Sesuai dengan pendapat Bailey dalam Saptorini (2008) bahwa dalam pembelajaran sains, siswa diharapkan mampu menguasai keterampilan dan mengaplikasikannya dalam kehidupan seharihari. Pengaplikasian tersebut tidak dapat

\footnotetext{
*Corresponding Author:

Nama : Tin Rosidah,

Lembaga : Pendidikan Kimia, Universitas Muhammadiyah Semarang

Email : tinrosidah@gmail.com,
} 
dilakukan apabila keterampilan dasarnya belum terbentuk.

Keterampilan generik sains sangat penting dalam pembelajaran. Beberapa aspek yang diukur pada keterampilan generik sains harus dikuasai siswa secara keseluruhan dan seimbang khususnya pada mata pelajaran kimia. Ilmu kimia sebagai salah satu bidang ilmu sains menyediakan beragam pengalaman belajar untuk memahami konsep, proses sains, melatih kerja ilmiah dan sikap ilmiah siswa (Wahyana, 2001 dalam Rosidah, Tin., Andari, PA., dan VDR, Andri, 2017).

Berdasarkan observasi awal yang dilakukan di kelas X MIPA 1 diperoleh data bahwa siswa masih bingung dalam melakukan perhitungan dengan pemodelan matematika pada materi yang bersifat hitungan. Siswa cenderung mudah lupa terhadap materi pelajaran yang diberikan guru. Hal ini dikonfirmasi melalui wawancara kepada siswa yang menyatakan bahwa siswa sulit mengingat karena lebih mengandalkan hafalan tanpa memahami konsep. Sesuai hasil analisis bahwa keterampilan generik sains siswa pada pembelajaran kimia masih belum seimbang antar aspeknya. Padahal keterampilan generik sains perlu dimiliki siswa sebagai bekal untuk mempelajari ilmu pengetahuan yang lebih tinggi dan lebih kompleks. Aspek-aspek keterampilan generik sains siswa dalam mata pelajaran kimia harus dikembangkan lagi agar seimbang sehingga proses pembelajaran dapat berjalan dengan baik.

Keterampilan generik sains yang masih variatif ini belum terukur secara teratur pada setiap siswa. Pengukuran keterampilan generik sains siswa perlu dilakukan agar guru tahu karakteristik siswa, serta keterampilan yang dimilikinya, khususnya pada mata pelajaran kimia. Hal ini dapat menunjang guru dalam menentukan model pembelajaran yang akan digunakan pada kegiatan pembelajaran agar keterampilan generik sains dan prestasi belajar siswa meningkat dan lebih baik dari sebelumnya.

Salah satu materi yang membutuhkan penguasaan seluruh aspek keterampilan generik sains dalam mata pelajaran kimia yaitu stoikiometri. Stoikiometri sebagai materi mendasar dalam ilmu kimia dan menjadi prasyarat untuk mempelajari materi kimia berikutnya, terutama materi kimia yang melibatkan perhitungan kimia seperti konsepkonsep dalam kinetika kimia, reaksi kesetimbangan, kimia larutan, termokimia, dan lain-lain. Untuk menyelesaikan soal perhitungan kimia digunakan asas-asas stoikiometri, antara lain persamaan kimia dan konsep mol (Rohaenitasari, 2013).

Sebagai materi dasar, stoikiometri harus dikuasai dengan baik oleh siswa kelas X SMA sehingga dapat digunakan sebagai bekal untuk mempelajari materi kimia yang lebih kompleks. Keberhasilan siswa dalam memahami konsep stoikiometri ini berpengaruh terhadap penguasaan konsep kimia berikutnya (Rohaenitasari, 2013). Stoikiometri sangat erat kaitannya dengan keterampilan generik sains pada aspek bahasa simbolik yaitu pada simbolsimbol rumus empiris, rumus molekul, dan molaritas, pembangunan konsep hukum-hukum kimia, konsep mol, dan stoikiometri, logika taat asas terutama dalam penerapan hukum-hukum kimia dan konsep mol pada stoikiometri, dan inferensi logika yaitu menarik kesimpulan dari konsep-konsep yang telah dipelajari.

Salah satu pendekatan yang mampu meningkatkan kualitas proses pembelajaran yaitu dengan mempergunakan aspek budaya lokal atau pengetahuan asli masyarakat yang disebut etnosains (Sudiana dan Surata, 2010; Atmojo, 2012; Kartimi, 2014; Rosyidah, Sudarmin dan Kusoro, 2013; Rahayu dan Sudarmin, 2015; Anwari, Nahdi, dan Sulistyowati 2016; Arfianawati, Sudarmin, dan Sumarni, 2016). Pengetahuan yang dimiliki suatu suku bangsa tertentu sering disebut sebagai pengetahuan sains masyarakat atau Indigenous Science (Sudarmin, 2014). Okechukwu, Lawrence dan Njoku (2014) menjelaskan etnosains sebagai pengetahuan asli yang berasal dari budaya dan bahasa yang menggambarkan suatu sistem yang unik dari pengetahuan asli dan pengetahuan teknologi. Adanya pendekatan etnosains mampu mentransformasikan sains asli (pengetahuan yang berkembang di masyarakat) menjadi sains ilmiah yang diajarkan di sekolah formal.

Menurut Rosidah, T., Fitria, FH., dan Andari, PA. (2018) pendekatan etnosains merupakan pendekatan yang sesuai untuk meningkatkan prestasi belajar siswa. Keterampilan generik sains sebagai keterampilan dasar yang dapat menjadi tolak ukur peningkatan prestasi belajar siswa. Jika keterampilan generik sains siswa baik, maka prestasi belajarnya juga baik. Pengetahuan dan permasalahan di masyarakat mampu menjadi stimulus bagi siswa dalam mempelajari materi 
stoikimetri. Hal ini didukung oleh penelitian Arfianawati, Sudarmin, dan Sumarni (2016) yang menyatakan bahwa penerapan Model Pembelajaran Kimia Berbasis Etnosains (MPKBE) dapat meningkatkan kemampuan kognitif dan berpikir kritis siswa karena mengaitkan pembelajaran di kelas dengan apa yang siswa temui di kehidupan sehari-hari dan juga mendorong siswa untuk berperan aktif dalam proses belajar. Hal ini juga didukung dengan pernyataan Rai dalam Arfianawati, Sudarmin, dan Sumarni (2016) bahwa guru harus menjembatani pengetahuan mainstream dengan kearifan lokal yakni dengan menggunakan aspek-aspek kearifan lokal dalam pembelajaran.

\section{Menurut}

Sudjana

dalam

Puspitaningrum, VR, Saptorini, dan Kusoro (2012), belajar berdasarkan masalah adalah interaksi antara stimulus dengan respons yang menghubungkan antara dua arah belajar dan lingkungan. Adapun model pembelajaran yang sesuai dengan pendekatan etnosains salah satunya yaitu model pembelajaran Problem Based Instruction (PBI). Menurut Rosidah, T., Fitria, FH., dan Andari, PA. (2018) pembelajaran berbasis masalah atau Problem Based Instruction (PBI) diterapkan untuk membantu siswa mengembangkan kemampuan berpikir, pemecahan masalah, keterampilan intelektual, dan menjadi siswa yang otonom serta mandiri. Berdasarkan pendapat Amelia, dkk (2014), model pembelajaran Problem Based Instruction ini bersifat konstruktivis yang melibatkan siswa dalam belajar dan pemecahan masalah, artinya model pembelajaran PBI ini berpusat pada siswa sehingga siswa dapat aktif dalam kegiatan pembelajaran. Peran guru berfokus pada membantu siswa untuk menemukan sendiri konsep pelajarannya dengan memberikan masalah kepada siswa dan meningkatkan aktivitas pembelajaran siswa, sehingga siswa tidak hanya mendengar, mencatat, dan menghafal konsep yang telah siswa dapatkan yang menjadikan siswa pembelajar yang pasif.

Pemilihan model pembelajaran
Problem Based Instruction (PBI) berpendekatan etnosains ini diharapkan mampu meningkatkan keterampilan generik sains siswa pada materi stoikiometri. Berdasarkan permasalahan di atas, maka dibutuhkan upaya guna meningkatkan keterampilan generik sains siswa dan mempermudah siswa dalam belajar kimia dengan menstransformasikan pengetahuan lokal dan permasalahan yang ditemui di masyarakat sebagai stimulus untuk mempelajari materi stoikiometri. Berkaitan dengan permasalahan di atas penulis melakukan penelitian yang berjudul "Efektivitas Model Pembelajaran Problem Based Instruction Berpendekatan Etnosains untuk Meningkatkan Keterampilan Generik Sains Siswa pada Materi Stoikiometri”.

\section{METODE PENELITIAN}

Penelitian ini dilaksanakan di SMA Muhammadiyah Gubug pada tanggal 27 April 2018 sampai 10 Mei 2018. Jenis penelitian yang digunakan yaitu kuasi eksperimen dengan rancangan times series design, yaitu pelaksanaan pretest dan postest dilakukan beberapa kali untuk mengetahui kestabilan keadaan siswa dalam perlakuan baik sebelum maupun sesudah perlakuan. Pada penelitian ini, ada lima aspek keterampilan generik sains yang diukur, yaitu membangun konsep, pemodelan matematika, bahasa simbolik, pengamatan langsung, dan pengamatan tidak langsung. Kelima aspek tersebut diamati dan diukur secara bergantian pada saat pemberian treatment dengan model pembelajaran problem based instruction berpendekatan etnosains. Kelas yang digunakan hanya satu kelas eksperimen. Menurut Sugiyono (2012) desain ini digunakan karena pada kenyataannya sulit mendapatkan kelompok kontrol yang digunakan untuk penelitian. Hal ini disebabkan kelompok kontrol tidak dapat berfungsi sepenuhnya untuk mengontrol variable-variabel luar yang mempengaruhi pelaksanaan penelitian. Teknik pengambilan sampel menggunakan purposive sampling, yaitu memilih sampel dengan mempertimbangkan beberapa syarat tertentu. Pada penelitian ini, peneliti menetapkan sampel berdasarkan ciri dan karakter prestasi belajarnya yang kurang dari KKM. Teknik pengumpulan data dilakukan dengan observasi, tes prestasi belajar, wawancara terbuka, dokumentasi, dan angket respon siswa.

Instrumen penelitian yang digunakan yaitu lembar soal dan lembar observasi. Data pretest dan postest dijadikan dasar perhitungan $\mathrm{N}$-Gain. Sedangkan nilai Gain digunakan untuk uji efektivitas. Untuk mengetahui pengaruh model pembelajaran problem based instruction berpendekatan etnosains terhadap keterampilan generik sains siswa, data postest diuji dengan 
menggunakan uji t. Untuk mengetahui seberapa besar pengaruh yang disebabkan oleh model pembelajaran problem based instruction berpendekatan etnosains dalam meningkatkan keterampilan generik sains siswa digunakan uji efektivitas dengan effect size.

\section{HASIL DAN PEMBAHASAN}

Pada penelitian ini, ada lima aspek keterampilan generik sains yang diukur. Adapun tahap penilaian kelima aspek tersebut dapat dilihat pada tabel 4.1 sebagai berikut:

Tabel 4.1 Data Penilaian Aspek KGS pada Setiap Pertemuan

\begin{tabular}{|c|c|c|}
\hline No. & $\begin{array}{l}\text { Pertemuan } \\
\text { ke- }\end{array}$ & Aspek yang Diamati \\
\hline 1. & Satu & $\begin{array}{l}\text { 1. Membangun konsep (MK) } \\
\text { 2. Bahasa simbolik (BS) }\end{array}$ \\
\hline 2. & Dua & $\begin{array}{l}\text { 1. Membangun konsep (MK) } \\
\text { 2. Pemodelan matematika (PM) } \\
\text { 3. Pengamatan langsung (PL) }\end{array}$ \\
\hline 3. & Tiga & $\begin{array}{l}\text { 1. Pemodelan matematika (PM) } \\
\text { 2. Bahasa simbolik (BS) } \\
\text { 3. Pengamatan tidak langsung } \\
\text { (PTL) }\end{array}$ \\
\hline
\end{tabular}

Berdasarkan pengumpulan data yang telah dilakukan di SMA Muhammadiyah Gubug pada mata pelajaran kimia materi stoikiometri diperoleh data sebagai berikut:

Tabel 1. Rekapitulasi Nilai Prestasi Belajar Siswa

\begin{tabular}{ccccc}
\hline $\begin{array}{c}\text { Aspek } \\
\text { Keterampilan } \\
\text { generik Sains }\end{array}$ & $\begin{array}{c}\text { Rata- } \\
\text { rata } \\
\text { Pretest }\end{array}$ & $\begin{array}{c}\text { Rata- } \\
\text { rata } \\
\text { Postes } \\
\boldsymbol{t}\end{array}$ & $\begin{array}{c}\text { N- } \\
\text { Gain }\end{array}$ & $\begin{array}{c}\text { Kriteria } \\
\text { N-Gain }\end{array}$ \\
MK & 7,34 & 79,25 & 0,776 & Tinggi \\
PM & 9,72 & 66,17 & 0,625 & Sedang \\
BS & 8,05 & 63,88 & 0,607 & Sedang \\
PL & 8,92 & 75 & 0,725 & Tinggi \\
PTL & 30 & 72,32 & 0,604 & Sedang \\
\hline
\end{tabular}

Nilai pretest yang rendah ini membuktikan bahwa kemampuan siswa dalam menguasai keterampilan generik sains masih sangat kurang dan harus ditingkatkan, mengingat siswa sudah berada pada jenjang kelas X SMA yang akan menemukan lebih banyak masalah kompleks yang harus dipecahkan. Keterampilan generik sains sebagai keterampilan yang mendasar seharusnya sudah dimiliki siswa dari jenjang sekolah dasar untuk mempermudah siswa dalam menguasai keterampilan berpikir tingkat tinggi dan keterampilan lain.
Berdasarkan data observasi di kelas pada saat pembelajaran diketahui bahwa masih banyak siswa yang belum menguasai keterampilan generik sains dengan baik seperti membangun konsep, pemodelan matematika, dan bahasa simbolik. Siswa masih sulit menemukan konsep pada materi yang dipelajari sehingga masih bingung dan belum paham terhadap materi stoikiometri yang diajarkan. Siswa belum mahir dalam melakukan perhitungan pada pemodelan matematika sehingga kesulitan dalam menyelesaikan masalah yang diberikan. Siswa juga belum mampu mengenali simbol-simbol yang sering dijumpai dalam materi kimia khususnya stoikiometri, baik itu simbol satuan, maupun rumus. Hal ini juga diperkuat dengan data hasil wawancara terbuka dengan seorang siswa yang sulit memahami konsep karena simbol dan rumus yang berbeda. "Saya belum mampu memahami konsep materi stoikiometri karena rumus dan simbolnya berbeda padahal namanya sama, misal massa zat dan massa molar. Keduanya sama-sama massa tetapi rumus untuk menentukan dan simbolnya berbeda," komentar salah seorang siswa kelas X MIPA 1 yang diwawancarai.

Hasil N-Gain menunjukkan adanya peningkatan lima aspek keterampilan generik sains siswa setelah kegiatan pembelajaran. Berdasarkan tabel 4.2 diperoleh hasil N-Gain pada setiap aspek berada pada kategori tinggi dan sedang. Artinya, penggunan model pembelajaran problem based instruction berpendekatan etnosains ini memberikan pengaruh yang baik dalam meningkatkan keterampilan generik sains siswa.

Pengujian normalitas data keterampilan generik sains siswa dilakukan dengan tujuan untuk mengetahui apakah data yang diperoleh terdistribusi normal atau tidak. Uji normalitas yang digunakan yaitu menggunakan uji Kolmogorov-Smirnov dengan taraf signifikan $\propto=0,05$. Berdasarkan hasil uji normalitas dengan taraf signifikan 0,05 diperoleh hasil bahwa data ada yang terdistribusi normal, ada pula yang tidak terdistribusi normal. Interpretasi uji normalitas yaitu data dikatakan normal jika nilai sig $>0,05$. Sebaliknya, jika nilai sig $<0,05$ maka data tidak normal. Pada uji normalitas diketahui data yang terdistribusi normal yaitu data aspek pemodelan matematika dengan nilai sig 0,839 , aspek pengamatan tidka langsung dengan nilai sig 0,061, dan aspek bahasa simbolik dengan nilai sig 0,903. 
Sedangkan data aspek membangun konsep dan pengamatan langsung tidak terdistribusi normal karena nilai sig nya $<0,05$. Dari penyebaran data yang normal dan tidak normal ini dapat disimpulkan bahwa data postest keseluruhan yaitu semi parametris. Pengujian data semi parametris disesuaikan dengan data non parametris.

Data pada aspek membangun konsep tidak normal karena masih ada siswa yang belum menguasai konsep. Siswa terkadang salah menerapkan konsep dalam soal, sebagai contoh dalam menentukan mol dan molaritas. Pada aspek pengamatan langsung data yang diperoleh juga tidak normal karena siswa belum mampu menyimpulkan percobaan yang dilakukan. Sebagai contoh, pada percobaan sederhana yang telah dilakukan untuk membedakan larutan berkonsentrasi rendah dengan larutan berkonsentrasi tinggi berdasarkan komposisi zat pelarut dan zat terlarutnya. Beberapa siswa yang belum menguasai aspek membangun konsep dan pengamatan langsung ini mendapatkan nilai rendah sehingga mempengaruhi distribusi data tidak normal meskipun instrumen soal yang digunakan sebagai alat ukur sudah valid dan reliabel. Data yang tidak normal juga dipengaruhi oleh jumlah sampel yang sedikit. Data yang tidak terdistribusi normal sebenarnya dapat dibuang agar dapat memenuhi asumsi klasik normalitas data, tetapi karena sampelnya sedikit, data yang diperoleh tidak dapat dikurangi.

Pengujian hipotesis dilakukan untuk menguji apakah terdapat pengaruh perlakuan (penerapan model pembelajaran) terhadap prestasi belajar. Interpretasi pengujian hipotesis menggunakan uji t yaitu dengan melihat nilai Sig (2 tailed) atau $\mathrm{p}$ value. Pada data pengujian hipotesis keterampilan generik sains siswa pada kelima aspek yang diteliti diperoleh nilai Sig (2 tailed) sebesar 0,00 dimana $0,00<0,05$. Karena nilai Sig ( 2 tailed) $<0,05$ maka terdapat perbedaan bermakna (signifikan) penggunaan model pembelajaran problem based instruction berpendekatan etnosains ditinjau dari keterampilan generik sains siswa kelas $\mathrm{X}$ pada materi stoikiometri pada taraf kepercayaan 5\%.

Efektivitas pada penelitian ini diukur menggunakan effect size. Effect size dapat dihitung dengan formulasi yang dijabarkan oleh hake. Efektivitas diukur dengan perbandingan gain dengan nilai postest lima aspek yang diteliti dengan standar deviasinya. Hasil uji effect size dapat dilihat pada tabel 2 di bawah ini:

Tabel 2. Hasil Uji effect size

\begin{tabular}{cccc}
\hline Aspek & Effect & Interpretasi & Kriteria \\
KGS & Size & $(\%)$ & \\
MK & 2,26 & $98 \%$ & Tinggi \\
PM & 1,77 & $96 \%$ & Tinggi \\
BS & 1,75 & $96 \%$ & Tinggi \\
PL & 2,07 & $98 \%$ & Tinggi \\
PTL & 1,33 & $92 \%$ & Tinggi \\
\hline
\end{tabular}

Berdasarkan tabel 2 diperoleh bahwa model PBI berpendekatan etnosains mempengaruhi keterampilan generik sains dengan nilai effect size $\geq 80 \%$. Sehingga dapat disimpulkan bahwa model pembelajaran PBI (Problem Based Instruction) berpendekatan etnosains efektif meningkatkan keterampilan generik sains siswa pada mata pelajaran kimia materi stoikiometri.

Penelitian ini memiliki acuan dalam menentukan keberhasilan penelitian, di antaranya dengan melihat ketuntasan nilai individu pada mata pelajaran kimia materi stoikiometri setelah melaksanakan pembelajaran dengan model pembelajaran problem based instruction berpendekatan etnosains. Ketuntasan nilai keterampilan generik sains setiap siswa (individu) dapat dilihat pada tabel 3 sebagai berikut:

Tabel 3. Ketuntasan Individu Keterampilan Generik Sains

\begin{tabular}{lcc}
\hline \multicolumn{1}{c}{ Aspek KGS } & $\begin{array}{c}\text { Nilai } \\
\text { Postest }\end{array}$ & Kriteria \\
MK & 79,25 & Tuntas \\
PM & 66,17 & Tidak tuntas \\
BS & 63,88 & Tidak tuntas \\
PL & 75 & Tuntas \\
PTL & 72,32 & Tuntas \\
Rata-rata nilai & $\mathbf{7 1 , 3 2}$ & Tuntas \\
\hline
\end{tabular}

Uji ketuntasan individual keterampilan generik sains siswa ini diperoleh hasil siswa tuntas dengan nilai $\geq \operatorname{KKM}(70)$, yaitu 71,32.

Uji ketuntasan klasikal digunakan untuk mengetahui keterampilan generik sains pada materi stoikiometri yang mencapai ketuntasan dalam satu kelas. Ketuntasan klasikal keterampilan generik sains siswa dalam satu kelas dapat dilihat pada tabel 4 sebagai berikut:

Tabel 4. Ketuntasan Klasikal Keterampilan Generik Sains

\begin{tabular}{lll}
\hline Aspek KGS & Proporsi & Kriteria \\
\hline
\end{tabular}




\begin{tabular}{ccc}
\hline & Tuntas & \\
MK & $71,42 \%$ & Tuntas \\
PM & $42,85 \%$ & Tidak tuntas \\
BS & $32,14 \%$ & Tidak tuntas \\
PL & $60,71 \%$ & Tidak tuntas \\
PTL & $71,42 \%$ & Tuntas \\
Rata-rata nilai & $\mathbf{5 5 , 7 0 \%}$ & Tidak Tuntas \\
\hline
\end{tabular}

Dalam penelitian ini, nilai rata-rata kelima aspek keterampilan generik sains yang diperoleh sebesar 55,70\%. Artinya, ketuntasan klasikal keterampilan generik sains tidak terpenuhi atau tidak tuntas. Hal ini disebabkan tidak semua aspek keterampilan generik sains yang diteliti dalam penelitian ini. Dari sepuluh aspek keterampilan generik sains yang diketahui menurut para ahli, hanya lima aspek yang diteliti dalam penelitian ini. Jadi, nilai ketuntasan klasikal yang tidak mencapai $75 \%$ ini hanya mencakup pada aspek keterampilan generik sains yang diukur pada penelitian ini saja, yaitu aspek membangun konsep, bahasa simbolik, pemodelan matematika, pengamatan langsung, dan pengamatan tidak langsung.

Berdasarkan pembahasan hasil penelitian yang diperoleh pada penelitian ini terbukti bahwa model pembelajaran problem based instruction (PBI) berpendekatan etnosains efektif untuk meningkatkan keterampilan generik sains siswa pada materi stoikiometri. Menurut Rosidah, T., Fitria, FH., dan Andari, PA. (2018) dengan model pembelajaran problem based instruction (PBI) berpendekatan etnosains ini siswa dapat mengekplor pengetahuan asli masyarakat dan dikaitkan dengan pengetahuan sains yang dipelajari di sekolah. Siswa dilatih untuk menyelesaikan suatu masalah dengan teman melalui diskusi. Siswa juga dilatih untuk saling kerja sama serta berani mengungkapkan pendapatnya. Sedangkan guru tetap menjadi fasilitator dalam pembelajaran dengan tetap membimbing siswa jika siswa menemukan kesulitan dalam menyelesaikan masalah.

Model pembelajaaran problem based instruction berpendekatan etnosains memiliki keterkaitan dengan pengetahuan masyarakat asli yang ada di sekitar lingkungan siswa sehingga dapat membantu siswa untuk memahami materi stoikiometri. Hasil-hasil penelitian ini menunjukkan bahwa penggunaan pengetahuan asli masyarakat (etnosains) dalam pembelajaran sangat penting dan perlu diterapkan. Model pembelajaran problem based instruction berpendekatan etnosains melatih siswa untuk belajar mandiri, aktif, dan kreatif dalam proses pembelajaran sehingga peran guru hanya sebagai fasilitator dan memberikan kesempatan pada siswa untuk terlibat langsung dalam proses pembelajaran dan dapat menemukan konsep sendiri dalam memahami materi yang disampaikan oleh guru. Hal ini sejalan dengan penelitian yang dilakukan oleh Soviani (2017), Kharista, Antonius, dan Tjahyo (2012), dan Mergendoller, dkk (2006).

Atmojo (2012) menjelaskan bahwa penerapan pendekatan etnosains memberikan dampak pada peningkatan hasil belajar siswa. Peningkatan ini disebabkan adanya kegiatan mengaitkan antara budaya yang berkembang di masyarakat dengan pembelajaran sains. Penerapan pendekatan etnosains dapat memberikan keleluasaan pada siswa untuk terlibat langsung pada kegiatan pembelajaran sehingga siswa memiliki pemahaman yang lebih baik dari siswa belajar secara konvensional. Lebih lanjut, Jegede dan Okebukola (1989) menyatakan bahwa memadukan sains asli siswa (sains sosialbudaya) dengan pelajaran sains di sekolah dapat meningkatkan prestasi belajar siswa. Hal ini sejalan dengan pernyataan bahwa jika prestasi belajar baik, tentu saja keterampilan generik sains siswa baik. Karena keterampilan generik sains merupakan keterampilan dasar yang menjadi dasar dalam penguasaan keterampilan yang lain. Jika dalam proses pembelajaran sains, keyakinaan atau pandangan tradisional tentang alam semesta tidak dimasukkan maka konflik yang ada pada diri siswa tentang perbedaan pandangan tradisional dan pandangan ilmiah akan terus dibawa oleh siswa dan akan berakibat pada memahaman siswa terhadap konsep ilmiah menjadi kurang bermakna.

Model pembelajaran Problem Based Instruction (PBI) berpendekatan etnosains sudah mampu mengatasi kesulitan belajar kimia pada materi stoikiometri. Hal ini dibuktikan dengan adanya peningkatan nilai postest setelah pembelajaran dan didukung dengan hasil observasi siswa yang dilakukan pada setiap perlakuan. Siswa awalnya sulit membedakan massa zat dan massa mol serta submateri lain yang ada pada konsep mol, namun setelah melakukan pembelajaran dengan problem based instruction berpendekatan etnosains siswa mampu memahami pengertian, rumus untuk menentukan, serta penerapannya dalam soal. Siswa juga dapat mengkontruksi 
pengetahuan baru yang diperoleh dari masalahmasalah yang disajikan dalam lembar diskusi berpendekatan etnosains sehingga pembelajaran yang dilakukan siswa dapat bermakna.

Dengan demikian, pembelajaran dengan pendekatan etnosains membawa pengaruh terhadap proses pembelajaran siswa, yaitu pengaruh positif jika pembelajaran kimia yang ada di sekolah selaras dengan pengetahuan asli masyarakat sekitar dan pembelajaran berpusat pada siswa akan berjalan dengan baik dan efektif jika proses asimilasi dan akomodasi belajar siswa juga berjalan dengan efektif.

Berdasarkan penelitian yang telah dilakukan, dapat disimpulkan mengenai keunggulan pembelajaran dengan menggunakan model pembelajaran PBI berpendekatan etnosains adalah sebagai berikut: (1) lebih tercipta suasana pembelajaran kimia yang aktif dan menyenangkan karena terdapat kegiatan diskusi sehingga pembelajaran benar-benar terpusat pada siswa, (2) memotivasi siswa agar dapat memecahkan masalah yang disajikan dalam lembar diskusi, (3) siswa lebih kreatif dalam berpikir dan memecahkan masalah, hal ini merupakan karakteristik model PBI yang membantu siswa mengembangkan keterampilan generik sains melalui pemecahan masalah dan menjadi siswa yang mandiri, (4) melatih siswa untuk bekerjasama menyelesaikan masalah, (5) siswa dapat belajar menjadi peneliti karena siswa dilatih untuk merencanakan penelitian awal hingga pemaparan hasil, (6) siswa menyadari bahwa materi stoikiometri yang dipelajarinya ternyata banyak diterapkan dalam kehidupan dan sudah menjadi pengetahuan asli masyarakat di sekitar lingkungan temat tinggalnya.

Model pembelajaran PBI berpendekatan etnosains juga memiliki kelemahan, yaitu hanya dapat digunakan untuk materi-materi pelajaran yang bersifat faktual dan prosedural, karena siswa dapat mengaitkan langsung dengan fakta-fakta di lapangan terkait pengetahuan sains yang dipelajari di sekolah dengan pengetahuan asli masyarakat. Penggunaan pendekatan etnosains tidak sesuai dengan materi-materi pelajaran yang bersifat abstraksi karena siswa akan sulit memahami dan mengaitkan pengetahuan abstraksi dengan pengetahuan asli masyarakat yang ada di sekitarnya.

\section{KESIMPULAN}

Model pembelajaran Problem Based Instruction (PBI) berpendekatan etnosains memiliki pengaruh yang signifikan dalam meningkatkan keterampilan generik sains siswa. Namun tidak efektif dalam meningkatkan keterampilan generik sains siswa karena ketuntasan klasikalnya $<75 \%$. Hal ini dikarenakan hanya ada lima aspek keterampilan generik sains yang diteliti sehingga belum dapat mewakili keterampilan generik sains secara keseluruhan.

Penerapan pendekatan etnosains dalam pembelajaran sangat beragam sesuai dengan lingkungan yang siswa tinggali. Oleh karena itu, guru yang akan menerapkan etnosains perlu untuk memahami pengetahuan-pengetahuan asli masyarakat.

\section{DAFTAR PUSTAKA}

Amelia, A, dkk. 2014. Penerapan Model Problem Based Instruction (PBI) Untuk Meningkatkan Keterampilan Proses Sains Di Sekolah Menengah Atas. Jurnal Pend. Kimia Vol. 1, No. 1, Halaman 1-8.

Anwari, Nahdi, M. S., dan Sulistyowati, E. 2016. Biological Science Learning Model Based on Turgo's Local wisdom on Managing Biodiversity. AIP Conference Proceedings 1708, doi:10.1063/ 1.4941146.

Arfianawati, S, Sudarmin, dan Woro Sumarni. 2016. Model Pembelajaran Kimia Berbasis Etnosains Untuk Meningkatkan Kemampuan Berpikir Kritis Siswa. Jurnal Pengajaran MIPA, Vol. 21, No. 1, Halaman 46-51.

Atmojo, S.E. 2012. Profil Keterampilan Proses Sains dan Apresiasi Siswa terhadap Profesi Pengrajin Tempe dalam Pembelajaran IPA Berpendekatan Etnosains. Jurnal Pendidikan IPA Indonesia, Vol. 1, No. 2, Halaman 115122

Jegede, OJ, dan P.A. Okebuloka. 1989. Influence of Socio-Cultural Factor on Secondary Students Attitude toward Science. Research in Science Education. 19.155-164.

Kartimi, 2014. Implementation Of Biology Learning Based On Local Science Culture To Improvement Of Senior High School Students Learning Outcome In 
Cirebon District And Kuningan District. Scientiae Educatia, Vol. 3, No. 2, Halaman 1-10.

Kharista, RY., Antonius, TR.,, dan Tjahyo Subroto. 2012. Pengaruh Model Problem Based Instruction Berbantuan Funny Worksheet terhadap Hasil Belajar dan Kreativitas. Jurnal Chem in Edu 2 No. 1, Halaman 62-68. ISSN: 2252-6609.

Mergendoller, John R, Maxwell, NL, and Yolanda Bellisimo. 2006. The Effectiveness of Problem Based Instruction: A Comparative Study of Instructional Methods and Student Characteristics. Journal IJPBL Volume 1 No. 2, PP: 49-69.

Okechukwu. S., Lawrence, A., and Njoku. 2014. Innovations in Science and Technology Education: A Case for Ethnoscience Based Science Classrooms. International Journal of Scientific and Engineering Research, Vol. 5 No.1, Halaman 52-56. ISSN: 2229-5518.

Purwanto, M. Ngalim. 2013. Prinsip-Prinsip dan Teknik Evaluasi Pengajaran. Jakarta: PT Remaja Rosda Karya.

Puspitaningrum, VR, Saptorini, dan Kusoro Siadi. 2012. Pengaruh Model Problem Based Instruction Berbantuan Elaboration Strategies terhadap Hasil Belajar. Jurnal Jurusan FMIPA Chem in Edu Vol. 2 No. 1, Halaman 142-147. Universitas Negeri Semarang. ISSN NO 2252-6609.

Rahayu, W. E., \& Sudarmin. 2015. Pengembangan Modul IPA Terpadu Berbasis Etnosains Tema Energi dalam Kehidupan untuk Menanamkan Jiwa Konservasi Siswa. Unnes Science Education Journal, Vol. 4, No. 2, Halaman 919-926. ISSN: 2252-6617.

Rosidah, Tin, Andari Puji Astuti, dan VDR Andri Wulandari. 2017. Eksplorasi Keterampilan Generik Sains (KGS) Siswa Pada Mata Pelajaran Kimia Di SMA Negeri 9 Semarang. Jurnal
Pendidikan Sains (JPS) Vol 5 No 2, Halaman 130-137. ISSN: 2339-0786.

Rosidah, T., Fitria, FH., dan Andari, PA. 2018. Efektivitas Model Pembelajaran Problem Based Instruction Berpendekatan Etnosains untuk Meningkatkan Prestasi Belajar Siswa pada materi Stikiometri. Prosiding Seminar Nasional Pendidikan Sains dan Teknologi. ISBN : 9-786025614354.

Rosyidah, A.N., Sudarmin, dan Kusoro, S. 2013. Pengembangan Modul IPA Berbasis Etnosains Zat Aditif Dalam Bahan Makanan untuk Kelas VIII SMP Negeri 1 Pegandon Kendal. Unnes Science Education Journal (USEJ) Vol. 2, No. 1, Halaman 133-139. ISSN: 22526609.

Siregar, Eveline dan Nara Hartini. 2010. Teori Belajar dan Pembelajaran. Bogor: PT Ghalia Indonesia.

Soviani, Iis. 2017. Efektivitas Model Pembelajaran PBI (Problem Based Intruction) Dan Model Pembelajaran Mind Mapping Terhadap Hasil Belajar Ditinjau Dari Pemahaman Konsep. Skripsi. Fakultas Tarbiyah Dan Keguruan Universitas Islam Negeri Raden Intan Lampung.

Sudarmin. 2014. Pendidikan Karakter, Etnosains dan Kearifan Lokal (Pertama ed.). Semarang: Fakultas Matematika dan Ilmu Pengetahuan Alam Universitas Negeri Semarang.

Sudiana, I.M., \& Surata, I.K. 2010. IPA Biologi Terintegrasi Etnosains Subak untuk Siswa SMP: Analisis tentang Pengetahuan Tradisional Subak yang Dapat Diintegrasikan dengan Materi Biologi SMP. Suluh Pendidikan Vol. 8, No. 2.

Sugiyono. 2012. Metode Penelitian Kuantitatif Kualitatif dan $R \& D$. Bandung: Alfabeta. 